\title{
STRATEGI PENCIPTAAN KOMUNITAS PEDULI DENGAN PENDEKATAN KOMPREHENSIF DI SEKOLAH DASAR
}

\author{
Sekar Purbarini Kawuryan \\ Universitas Negeri Yogyakarta Indonesia \\ E-mail: sekarpurbarini@uny.ac.id
}

\begin{abstract}
Abstrak: Penelitian ini bertujuan untuk mendeskripsikan strategi penciptaan komunitas peduli dengan pendekatan komprehensif di sekolah dasar. Jenis penelitian adalah analisis konten inferensial. Prosedur penelitian yang dilakukan mencakupi pengadaan dan reduksi data. Sumber data berupa empat artikel jurnal yang memiliki fokus penelitian yang sama. Unit data menggunakan unit fisik dengan sampel unit berupa konteks tentang caring classroom sebagai bentuk implementasi Child Development Project (CDP) yang dipublikasikan pada tahun 1990-1996 dan diakses melalui Google Scholar. Teknik analisis data dilakukan secara kualitatif menggunakan peta kognitif, yaitu mencari kesesuaian pemikiran penulis artikel jurnal tentang strategi penciptaan komunitas peduli pada tahun tersebut dengan realitas saat sekarang. Semua data diringkas, dipahami, diinterpretasikan, diinferensikan, dan ditemukan pola hubungan dengan situasi terkini tentang fenomena kepedulian siswa SD. Penelitian ini menggunakan validitas semantis dan reliabilitas stabilitas (konsistensi). Konstruk analitis dibangun menggunakan teori kognitif dan afektif. Hasil penelitian menunjukkan bahwa komunitas peduli di sekolah dasar diciptakan menggunakan beberapa strategi, yaitu: (1) menciptakan hubungan asuh yang peduli; (2) mengajarkan nilai-nilai kemanusiaan; (3) menghormati motivasi intrinsik, dan (4) mengajarkan untuk memahami. Strategi tersebut dapat berjalan efektif dengan melibatkan peran dan tanggung jawab administrator, guru, konselor, orang tua, dan masyarakat secara komprehensif.
\end{abstract}

Kata Kunci: strategi, komunitas peduli, pendekatan komprehensif, sekolah dasar

\section{CREATION STRATEGY OF CARING COMMUNITIES USING COMPREHENSIVE APPROACH IN ELEMENTARY SCHOOLS}

\begin{abstract}
This study aims to describe the strategy of creating caring communities with a comprehensive approach in elementary school. The type of this research was inferential content analysis. The research procedures carried out include the procurement and reduction of data. The data sources were four journal articles that have the same research focus. The data unit used physical units with a sample unit in the form of context about caring classroom as a form of implementation of the Child Development Project (CDP) which was published in 1990-1996 and accessed through Google Scholar. The data analysis technique was carried out qualitatively using a cognitive map, which seeks to match the thinking of journal articles writers about the strategy of creating caring communities in that year with current realities. namely looking for the suitability of the thoughts of the authors of journal articles about the strategy of creating a caring community in that year with the current reality. All data were summarized, understood, interpreted, referenced, and found patterns of relationships with the current situation regarding elementary school students' concern phenomena. This study used semantic validity and stability reliability (consistency). Analytical constructs were built using cognitive and affective theory. The results show that the caring community in primary school was created using the following strategies: (1) creating the caring nurturing relationships; (2) teaching human values; (3) respecting intrinsic motivation; and (4) teaching to understand. The strategy can be effectively by involving the roles and responsibilities of administrators, teachers, counselors, parents, and the community comprehensively.
\end{abstract}

Keywords: strategy, caring community, comprehensive approach, elementary school

\section{PENDAHULUAN}

Manusia secara individu tidak dapat berkembang tanpa perhatian dan kepe- dulian. Sekolah sebagai sebuah komunitas menjadi medan eksperimen berdemokrasi 
bagi anak-anak. Komunitas pembelajar yang di dalamnya orang dewasa dan anak-anak dapat bersama-sama mengeksplorasi dan mempraktikkan kebersamaan serta hubungan timbal balik yang penting untuk mempertahankan kehidupan manusia dan masyarakat yang demokratis. Sekolah menduduki tempat sentral dalam agenda perkembangan anak-anak yang ditetapkan hampir setiap negara di dunia. Peran sentral sekolah dalam pendidikan anak-anak dan remaja tidak hanya berkaitan dengan membaca, menulis, dan berhitung, tetapi juga dalam hal moral dan pengembangan karakter, penanaman motivasi untuk belajar, keinginan untuk belajar sepanjang hayat, promosi keterampilan sosial-emosional dan kesejahteraan, serta pencegahan dan perbaikan masalahmasalah perilaku-emosional (Eccles \& Roeser, 2011). Konteks sekolah dan komunitas dapat mempengaruhi perkembangan anak dan remaja melalui penataan kelompok sebaya, jejaring sosial, dan melalui biaya untuk partisipasi dalam kegiatan terorganisasi yang menanamkan keterampilan, makna, dan hubungan yang memuaskan.

Sejumlah besar anak muda mengalami masalah dan terlibat dalam berbagai perilaku berisiko tinggi yang dapat membatasi potensi perkembangan menjadi anggota konstruktif yang berkontribusi dalam masyarakat, seperti penggunaan narkoba, perilaku seksual berisiko tinggi, kenakalan, dan bunuh diri (Dryfoos, 1994). Selain itu, interaksi manusia yang terjadi antara anak-anak dan orang dewasa di sekolah juga kurang berkualitas (Haynes, 1996). Anak-anak muda mengalami penurunan tanggung jawab sosial dan kepedulian terhadap orang lain (Battistich, 2008). Interaksi ini berkontribusi besar pada iklim sosial sekolah secara keseluruhan, yang meliputi sikap, nilai, dan perilaku siswa, staf sekolah, orang tua, serta anggota masyarakat satu sama lain dan terhadap kegiatan dan program yang terjadi di sekolah.

Iklim sekolah yang tidak sehat menyebabkan konflik antara anak-anak, orang tua, dan personil sekolah sehingga berdampak pada sulitnya perkembangan sosial dan intelektual anak-anak. Para guru, orang tua, dan siswa kurang berminat satu sama lain di sekolah. Mayoritas guru tidak mengetahui tujuan dan aspirasi orang tua untuk anak-anak mereka, upaya yang telah dilakukan orang tua, keinginan terlibat di sekolah dan di rumah, serta berbagai informasi yang diinginkan orang tua agar interaksi dengan anak-anak tentang tugas sekolah lebih efektif (Epstein, 2010). Oleh karena itu, intervensi keluarga, sekolah, dan masyarakat dapat mencegah perilaku bermasalah dan mempromosikan kompetensi sosial (Bronfenbrenner, 1979; Perry, Kelder, \& Komro, 1993).

Sekolah atau ruang kelas memainkan peran penting dalam sosialisasi moral sebagai perantara antara moralitas afektif keluarga dan moralitas kehidupan sipil yang lebih ketat (Durkheim, 1961). Sekolah menjadi lembaga yang melatih anak masuk ke dalam masyarakat yang lebih besar, dengan semua tanggung jawab yang menyertainya untuk diri sendiri dan orang lain, seperti pentingnya mengikuti aturan dasar, kewajiban menghormati hak-hak orang lain, dan komitmen untuk kesejahteraan umum individu dan komunitas. Anak-anak mengembangkan aspek sentral dari karakter yang baik dengan mengamati, mengalami, dan mempraktikkan aspek-aspek tersebut di sekolah.

Secara khusus, konsep sekolah sebagai sebuah "komunitas" menjadi sangat umum dalam diskusi sekolah yang efektif 
(Brandt, 1992; Hallinger \& Murphy, 1986; Sizer, 1984), Siswa dan guru memperoleh berbagai manfaat melalui peran sekolah sebagai komunitas (Arhar \& Kromrey, 1993; Bryk \& Driscoll, 1988; Goodenow, 1993; Hallinger \& Murphy, 1986). Komunitas memiliki istilah geografis dan sosialpsikologis atau makna relasional, keduanya dapat diterapkan ke sekolah. Sekolah adalah tempat yang di dalamnya orang berinteraksi dengan difokuskan pada kualitas hubungan sosial antaranggota. Secara konseptual, komunitas didefinisikan sebagai tempat yang di dalamnya anggota: (a) peduli dan saling mendukung; (b) berpartisipasi aktif dalam dan memiliki pengaruh pada kelompok kegiatan dan keputusan; (c) saling merasa memiliki dan identifikasi dengan kelompok; dan (d) memiliki norma, tujuan, dan nilai yang sama (Bryk \& Driscoll, 1988; McMillan \& Chavis, 1986). Selain itu, juga dapat didefinisikan sebagai lingkungan yang dicirikan oleh dukungan dan kepedulian bersama, kerja kolaboratif dan pengambilan keputusan (Battistich et al., 1994).

Sebuah sekolah yang mirip keluarga mengakui individualitas setiap anak dan membuatnya merasa istimewa. Komunitas, termasuk kelompok orang tua yang bekerja bersama, menciptakan peluang, acara, dan program yang memperkuat, mengenali, dan memberi penghargaan kepada siswa untuk kemajuan, kreativitas, kontribusi, dan keunggulan yang baik (Epstein, 2010). Masyarakat juga menciptakan pengaturan, layanan, dan berbagai acara yang memungkinkan keluarga mendukung anak-anak dengan lebih baik. Penggabungan konsep semacam ini menyediakan komunitas peduli bagi anakanak (Brandt 1989; Epstein, 1987; Lewis, Schaps, \& Watson 1995).

Komunitas belajar yang peduli mem- bantu memenuhi kebutuhan anak-anak untuk mempunyai rasa memiliki, kontrol terhadap lingkungan, dan kebutuhan dasar manusia sebagaimana diidentifikasi oleh banyak psikolog perkembangan dan motivasi (Connell, 1990; Deci \& Ryan, 1985; Eccles et al., 1993; Erikson, 1950; Glasser, 1969). Lingkungan inklusif, penuh rasa hormat yang kaya akan pertemanan memberikan rasa memiliki. Lingkungan yang membuat siswa merasa diperhatikan dan diperlakukan dengan adil dan baik oleh guru dan teman sekelasnya, akan membantu anak-anak belajar logika timbal balik dan mengembangkan keinginan untuk berperilaku sama terhadap orang lain.

Siswa sekolah dasar harus banyak belajar supaya mampu memperlakukan orang lain secara adil dan ramah dengan dasar yang konsisten. Peran guru di sekolah, tidak hanya harus memodelkan karakter yang baik, tetapi juga mengajarkan keterampilan dan pemahaman yang dibutuhkan siswa. Kehidupan kelas seharusnya menawarkan kesempatan belajar terus-menerus dan mempraktikkan kebiasaan berkarakter baik. Sebagai contoh, di kelas siswa dapat belajar keterampilan seperti cara menyelesaikan konflik melalui penalaran yang adil dan bernegosiasi berbagi tugas. Menjadi bagian dari komunitas kelas yang peduli dapat mempengaruhi perkembangan karakter anak dalam dua cara (Watson, 1999), yaitu anak-anak mengalami dan mengidentifikasi nilainilai dan tujuan-tujuan komunitas secara mandiri dan guru membantu siswa memperoleh penilaian, kepekaan, kontrol diri, dan keterampilan untuk dapat memperlakukan orang lain dengan baik.

Ciri-ciri seseorang yang berkarakter baik secara sederhana yaitu memperhatikan orang lain dan diri sendiri, menyadari 
perasaan dan kebutuhan orang lain, memahami implikasi moral dari tindakannya, memiliki kontrol diri dan keterampilan bertindak dengan cara yang menguntungkan orang lain, dan melakukannya karena kepedulian terhadap orang lain dan keinginan untuk berperilaku dengan cara yang adil, baik, bertanggung jawab, dan jujur. Selain itu, orang yang berkarakter baik tidak melukai atau mengambil keuntungan dari orang lain, jujur, dan menawarkan bantuan ketika dibutuhkan. Orang-orang berkarakter baik akan memperbaiki kesalahan tanpa rasa takut akan hukuman atau karena janji hadiah. Tindakan tersebut dilakukan karena kepedulian terhadap kesejahteraan orang lain dan komitmen terhadap nilai-nilai inti, seperti kebaikan, keadilan, dan tanggung jawab pribadi. Untuk mengembangkan komitmen terhadap nilai-nilai inti seperti itu, anak-anak harus merasa terhubung dengan model yang mengajarkan nilai-nilai tersebut.

Etika peduli berdampak nyata pada pendidikan moral. Keempat komponen pendidikan moral yang mencakupi pemodelan, dialog, praktik, dan konfirmasi (Noddings, 2002, 2005) bergantung pada keberhasilan menciptakan hubungan kepedulian. Seorang anak dapat memilih seseorang (atau karakter fiktif) sebagai model moral, baik secara sadar maupun tidak sadar. Orang dewasa yang peduli biasanya memiliki efek kuat ketika seorang anak merasa aman. Anak yang sedang tumbuh secara sadar menolak perlakuan kejam, tetapi menginternalisasi ketidakpedulian dari model yang buruk. Orang dewasa yang mengetahui perannya sebagai model memiliki tanggung jawab khusus untuk menunjukkan arti peduli dengan menampilkan kepedulian dan perhatian. Akan tetapi, perannya sebagai model seharusnya tidak membebani kepedulian yang sebenarnya. Oleh karena itu, efek pemodelan bergantung pada hubungan kepedulian dan kepercayaan.

Komponen kedua dalam pendidikan moral dari perspektif kepedulian adalah dialog yang tulus, lebih dari sekedar percakapan, meskipun percakapan juga dapat berkontribusi pada pendidikan moral (Noddings, 1994). Kedua pihak berbicara dan mendengarkan saat berdialog. Dialog yang berkaitan dengan kepedulian ditandai adanya perhatian terhadap yang lain. Topik dialog yang berpotensi menimbulkan pertengkaran dapat diubah dengan melibatkan perhatian (Noddings, 2002). Dialog yang tidak menghasilkan solusi bersama harus berakhir dengan cara yang menopang hubungan peduli.

Komponen ketiga adalah praktik atau berlatih. Orang tua dan guru yang baik memberikan kesempatan pada anakanak dan siswa untuk berlatih peduli. Praktik ini melibatkan latihan empati atau simpati, diawasi orang tua atau guru untuk memastikan interaksi yang tepat. Guru yang baik juga memperhatikan perilaku yang baik dan memuji anak untuk menunjukkan perhatian. Perilaku peduli bukan hanya harus dihargai, tetapi juga harus diakui. Peran hadiah untuk anakanak sebagai respons peduli dapat menggantikan dorongan peduli dari hati. Seseorang harus belajar secara sadar atau tanpa sadar tentang arti kepedulian sebelum mengimplementasikan kepedulian tersebut pada orang lain.

Komponen keempat adalah konfirmasi. Pendidik moral tidak hanya menarik perhatian anak-anak terhadap penyebab rasa sakit yang dimiliki, tetapi juga memuji anak-anak dengan motif yang secara moral lebih baik dari tindakan yang mengecewakan. Seorang guru dapat dengan 
jujur mengingatkan anak yang berkeinginan menyenangkan orang tuanya dengan nilai bagus, tetapi dengan cara mencontek. Guru harus menghargai motif mengagumkan yang dimiliki anak, tetapi harus juga terlibat dialog bahwa tindakannya tidak sesuai dengan motifnya. Konfirmasi mengarahkan seseorang ke arah diri yang lebih baik sehingga mewujud dalam bentuk tindakan moral yang indah. Pendidik moral harus mengenal anak dengan cukup baik untuk dapat memilih motif yang paling sesuai dengan kenyataan. Relasi kepedulian memungkinkan konfirmasi.

Penciptaan komunitas peduli oleh seorang guru di kelas memberikan konteks optimal untuk pengembangan karakter. Proses yang terlibat dalam menciptakan komunitas peduli membutuhkan figur guru yang adil dan peduli, memodelkan keterampilan dan sikap adil dan peduli sesuai kebutuhan anak-anak, dan memastikan bahwa setiap orang di masyarakat hidup dengan nilai-nilai ini (Watson, 1999). Selain itu, iklim ruang kelas yang positif memfasilitasi pembelajaran dan karenanya meningkatkan prestasi akademik siswa (Li, 1992). Banyak faktor yang berkontribusi pada perkembangan iklim kelas, termasuk rutinitas dan kegiatan harian, organisasi sosial kelas, interaksi sosial dan pedagogis antara guru dan siswa, interaksi sosial dan akademik di antara siswa, persepsi siswa tentang perilaku sosial dan akademik guru, dan efek perbedaan budaya dan sosial lainnya pada interaksi sosial di ruang kelas (Creemers \& Tillema, 1988; Brophy, 1988; Good, 1987; Rosenholtz, 1989; Li, 1992; Flores, Cousin, \& Diaz, 1991).

Semua siswa, terutama yang kurang berprestasi, terus-menerus melindungi ego dikelas (Hansen, 1989). Siswa yang menganggap guru atau tugas sebagai ancaman sedang terlibat dalam strategi perlindungan ego, yang dapat dikategorikan menjadi tiga, yaitu mengatasi (atau berusaha dengan keberhasilan parsial); dissembling (pura-pura mencoba atau melakukan pekerjaan); atau gagal. Guru dapat membujuk anak kurang berprestasi untuk meningkatkan upaya mengakui strategi perlindungan ego dan terus melibatkan siswa dengan menawarkan dukungan lisan, bimbingan, atau dengan membiarkan siswa mengetahui sendiri bentuk kepeduliannya. Siswa yang merasa memiliki atau menjadi bagian dari kelas menghasilkan skor lebih tinggi dibandingkan ukuran kontrol akademik yang dirasakan (Connell, 1990).

Selain itu, siswa yang merasa aman secara emosional dengan teman sekelas dan guru lebih cenderung menjadi peserta aktif dan mengerjakan tugas dengan sungguh-sungguh sehingga meningkatkan prestasi akademik (Connell \& Wellborn, 1990). Pengembangan interaksi teman sebaya yang mendukung iklim kelas yang kondusif mengharuskan guru secara aktif mengajar siswa tentang cara terlibat dalam interaksi sosial yang positif dalam pengaturan ruang kelas (Li, 1992). Oleh karena itu, ruang kelas yang menyediakan lebih banyak dukungan sosial dan emosional untuk siswa penting dilakukan guru dengan menggunakan beberapa strategi yang berbeda. Di sinilah pentingnya penelitian ini dilakukan untuk mengkaji berbagai strategi untuk penciptaan komunitas peduli secara komprehensif, terutama bagi anak-anak di sekolah dasar.

\section{METODE}

Jenis penelitian yaitu analisis konten inferensial. Prosedur analisis konten yang dilakukan mencakupi pengadaan dan reduksi data. Sumber data berupa empat artikel jurnal yang memiliki fokus peneliti- 
an yang sama. Unitiasi data menggunakan unit fisik dengan sampel unit konteks tentang caring classroom sebagai bentuk implementasi Child Development Project (CDP) yang dipublikasikan pada tahun 1990-1996 dan diakses melalui Google Scholar. Teknik analisis data dilakukan secara kualitatif menggunakan peta kognitif, yaitu mencari kesesuaian pemikiran penulis artikel jurnal tentang strategi penciptaan komunitas peduli pada tahun tersebut dengan realitas saat sekarang. Semua data diringkas, dipahami, diinterpretasikan, diinferensikan, dan ditemukan pola hubungan dengan situasi terkini tentang fenomena kepedulian siswa sekolah dasar (SD). Penelitian ini menggunakan validitas semantis dan reliabilitas stabilitas (konsistensi). Konstruk analitis dibangun menggunakan teori kognitif Howard Gardner (1999) tentang kecerdasan ganda (multiple intelligences) dan teori afektif Thomas Lickona (1985) tentang pendidikan moral.

\section{HASIL DAN PEMBAHASAN}

Di awal uraian bagian ini disajikan dulu hasil penelaahan terhadap empat artikel yang dijadikan sumber data dalam penelitian analisis isi ini. Tabel 1 dan Tabel 2 berikut menyajikan secara rinci hasil penelitian tersebut.

\section{Tabel 1. Sumber Data Penelitian}

\begin{tabular}{|c|c|c|c|c|}
\hline No. & Penulis Artikel & $\begin{array}{l}\text { Tahun } \\
\text { Terbit }\end{array}$ & $\begin{array}{c}\text { Sampel Penelitian } \\
\text { dalam Artikel }\end{array}$ & Fokus Penelitian \\
\hline & $\begin{array}{l}\text { Schaps, E., \& Solomon, } \\
\text { D. }\end{array}$ & 1990 & $\begin{array}{l}\text { - Guru kelas dari } 3 \\
\text { SD } \\
\text { - Siswa kelas 4, 5, } 6\end{array}$ & $\begin{array}{l}\text { - Upaya sekolah dalam mendorong } \\
\text { tanggung jawab sosial siswa } \\
\text { - Upaya sekolah menjadi komuni- } \\
\text { tas peduli yang di dalamnya se- } \\
\text { mua anak menjadi anggota yang } \\
\text { berkontribusi dan dihargai }\end{array}$ \\
\hline & $\begin{array}{l}\text { Battistich, V., Solomon, } \\
\text { D., Watson, M., \& } \\
\text { Schaps, E. }\end{array}$ & 1994 & Guru kelas dari 24 SD & $\begin{array}{l}\text { Pengembangan prososial dengan } \\
\text { memberikan siswa banyak kesem- } \\
\text { patan untuk: (a) berkolaborasi } \\
\text { dengan orang lain dalam mengejar } \\
\text { tujuan bersama; (b) memberikan } \\
\text { dan menerima bantuan orang lain; } \\
\text { (c) mendiskusikan dan } \\
\text { merefleksikan pengalaman untuk } \\
\text { mendapatkan pemahaman dan } \\
\text { penghargaan orang lain }\end{array}$ \\
\hline & Cabello, B., \& Terrell, R. & 1994 & $\begin{array}{l}\text { - } 10 \text { guru teladan dari } \\
2 \text { sekolah, } \\
\text { - Siswa kelas 3-6 SD, } \\
\text { - } 9 \text { ruang kelas }\end{array}$ & $\begin{array}{l}\text { - Organisasi sosial kelas } \\
\text { - Interaksi guru dan siswa } \\
\text { - Dukungan perilaku dan strategi } \\
\text { guru secara emosional } \\
\text { - Cara-cara guru mengembangkan } \\
\text { iklim kelas yang hangat }\end{array}$ \\
\hline 4. & Haynes, N., M. & 1996 & $\begin{array}{l}150 \text { sekolah (SD, SMP, } \\
\text { SMA) }\end{array}$ & $\begin{array}{l}\text { Mendukung perkembangan anak } \\
\text { dalam enam domain yang saling } \\
\text { terkait, yaitu fisik, bahasa, etika, } \\
\text { sosial, psikologis, dan akademik }\end{array}$ \\
\hline
\end{tabular}


Tabel 2 Perbedaan dan Persamaan Artikel Jurnal yang Dianalisis

\begin{tabular}{|c|c|c|c|}
\hline No. & Fokus Karakter & Strategi Pengembangan Karakter & Hasil \\
\hline 1. & $\begin{array}{l}\text { Kebaikan } \\
\text { Perhatian } \\
\text { Kepedulian } \\
\text { Kesadaran, } \\
\text { Pemahaman } \\
\text { antarpribadi }\end{array}$ & $\begin{array}{l}\text { - Pembelajaran kooperatif (kolabo- } \\
\text { rasi teman sebaya, bimbingan } \\
\text { orang dewasa), } \\
\text { - Developmental discipline (pende- } \\
\text { katan manajemen kelas, perte- } \\
\text { muan berkala antarsiswa, bekerja } \\
\text { secara kolaboratif dengan guru) } \\
\text { - Pendekatan berbasis literatur un- } \\
\text { tuk pengajaran membaca (mem- } \\
\text { bantu siswa terampil membaca, } \\
\text { mengembangkan pemahaman } \\
\text { tentang nilai-nilai prososial dan } \\
\text { implementasinya dalam kehi- } \\
\text { dupan sehari-hari). }\end{array}$ & $\begin{array}{l}\text { - Siswa merasa menjadi bagian dari } \\
\text { komunitas } \\
\text { - Siswa sangat termotivasi untuk } \\
\text { mematuhi norma-norma } \\
\text { masyarakat }\end{array}$ \\
\hline 2. & $\begin{array}{l}\text { Kebaikan } \\
\text { Perhatian } \\
\text { Kepedulian } \\
\text { Kesadaran, } \\
\text { Pemahaman } \\
\text { antarpribadi }\end{array}$ & $\begin{array}{l}\text { - Meminimalkan pemberian insen- } \\
\text { tif ekstrinsik (poin, hadiah) di- } \\
\text { gunakan untuk mengontrol } \\
\text { perilaku siswa, dan hubungan } \\
\text { kompetitif siswa secara implisit } \\
\text { atau eksplisit } \\
\text { - Menekankan kerja sama dari- } \\
\text { pada kompetisi di kelas } \\
\text { - Memberi siswa lebih banyak oto- } \\
\text { nomi } \\
\text { - Melibatkan siswa secara aktif } \\
\text { dalam tata kelola kelas (mengem- } \\
\text { bangkan aturan dan norma kelas, } \\
\text { memecahkan masalah, dan mem- } \\
\text { buat keputusan tentang kegiatan } \\
\text { kelas). }\end{array}$ & $\begin{array}{l}\text { - Komunitas sekolah yang peduli } \\
\text { bermanfaat bagi semua siswa } \\
\text { - Komunitas sekolah yang peduli } \\
\text { memiliki banyak utilitas praktis } \\
\text { karena memberikan arahan yang } \\
\text { jelas untuk membantu sekolah } \\
\text { memenuhi kebutuhan guru dan } \\
\text { siswa secara lebih efektif. }\end{array}$ \\
\hline 3. & Kepedulian & $\begin{array}{l}\text { - Pembelajaran kooperatif } \\
\text { (kegiatan tim, kelompok, } \\
\text { atau kolaboratif) } \\
\text { - Tutor sebaya (membantu, } \\
\text { memuji, memberikan umpan } \\
\text { balik satu sama lain) }\end{array}$ & $\begin{array}{l}\text { - Siswa merasa menjadi bagian } \\
\text { kelompok; } \\
\text { - Siswa memiliki tanggung jawab } \\
\text { bersama untuk saling membantu; } \\
\text { - Siswa terlibat dalam interaksi sosial } \\
\text { yang memfasilitasi penyelesaian } \\
\text { pekerjaan akademik. } \\
\text { - Keterlibatan emosional guru } \\
\text { dengan mendengarkan cerita } \\
\text { siswa, memberikan pekerjaan dan } \\
\text { umpan balik, dan bersikap tegas } \\
\text { tetapi adil. }\end{array}$ \\
\hline & $\begin{array}{l}\text { Ketertiban, } \\
\text { Kedisiplinan, } \\
\text { Rasa hormat, } \\
\text { Kepedulian, } \\
\text { Keadilan }\end{array}$ & $\begin{array}{l}\text { - mempertahankan standar } \\
\text { akademik yang tinggi mela- } \\
\text { lui program kurikulum dan } \\
\text { akademik yang inovatif; } \\
\text { - memastikan keterlibatan } \\
\text { masyarakat dan orang tua } \\
\text { serta memberikan kegiatan } \\
\text { untuk meningkatkan inter- } \\
\text { aksi staf dan siswa; } \\
\text { - memastikan keamanan } \\
\end{array}$ & $\begin{array}{l}\text { Penciptaan iklim sekolah (ketertiban, } \\
\text { disiplin, kepedulian, kepekaan, keper- } \\
\text { cayaan, saling menghormati, kebaikan, } \\
\text { keadilan, akses yang sama, dan harap- } \\
\text { an yang tinggi) yang positif, suportif, } \\
\text { dan sehat tanpa kekerasan antarpri- } \\
\text { badi membutuhkan keterlibatan siswa, } \\
\text { guru, staf sekolah, orang tua, dan ma- } \\
\text { syarakat }\end{array}$ \\
\hline
\end{tabular}




\begin{tabular}{ll}
\hline No. Fokus Karakter $\quad$ Strategi Pengembangan Karakter & Hasil \\
\hline & sekolah dengan \\
& menyediakan lokakarya \\
& guru tentang keselamatan, \\
& disiplin, dan iklim; \\
& mendidik siswa dalam \\
& strategi pemecahan masalah \\
& tanpa kekerasan; \\
$\bullet$ & mempromosikan \\
& pembelajaran kooperatif di \\
& antara para siswa \\
\hline
\end{tabular}

Komunitas peduli dalam konteks kelas dimaknai sebagai komunitas yang memenuhi kebutuhan dasar siswa untuk otonomi, kompetensi, dan kepemilikan (Deci \& Ryan, 1985), yang di dalamnya individu memahami pentingnya nilai-nilai keadilan, kepedulian, dan tanggung jawab terhadap kehidupan dalam masyarakat yang demokratis melalui pengalaman langsung (Dewey, 1900). Siswa merasakan ikatan afektif yang kuat dengan siswa lain, dengan guru, merasa menjadi anggota komunitas, dan mengidentifikasi sebagai anggota masyarakat sehingga memotivasi untuk menegakkan norma-norma masyarakat dan menginternalisasi nilai-nilai masyarakat. Oleh karena itu, kelas yang peduli dengan masyarakat diharapkan memiliki efek positif pada perkembangan sosial, etika, dan intelektual siswa.

Berbagai aktivitas siswa sebagian besar dilakukan di ruang kelas. Proses belajar yang diperoleh di dalam kelas dapat memberikan efek berkelanjutan sehingga membutuhkan kesinambungan pengalaman. Dengan kata lain, siswa seharusnya mendapat banyak manfaat melalui partisipasi dalam komunitas peduli yang dilakukan selama bersekolah. Oleh karena itu, untuk menciptakan kesinambungan pengalaman, sekolah harus membentuk komunitas yang peduli, tidak hanya beberapa ruang kelas.

\section{Strategi Penciptaan Komunitas Peduli}

Beberapa strategi untuk penciptaan komunikasi peduli berdasarkan analisis isi beberapa artikel dijekaskan sebagai berikut.

\section{Menciptakan Hubungan Asuh yang Peduli}

Serangkaian kegiatan dan pendekatan yang digunakan guru untuk menjalin hubungan pengasuhan dengan dan di antara anak-anak dalam jurnal yang dikaji yaitu: (1) menciptakan banyak peluang untuk mengenal siswa, membantu siswa mengenal guru, dan membantu siswa saling mengenal dengan cara meminta siswa mewawancarainya dan teman-temannya tentang topik-topik yang menjadi minat bersama; meminta siswa mewawancarai anggota keluarga tentang tradisi keluarga, pengalaman masa kecil, dan sejarah keluarga; dan meminta siswa membagikan kepada kelas beberapa informasi yang diperoleh dari wawancara tersebut; (2) melakukan kegiatan menyenangkan yang membangun persatuan kelas dengan menyatukan keberagaman siswa dan menugasi untuk menulis sejarah kelas, membuat mural kelas, merencanakan perjalanan kelas, atau menyelidiki topik-topik yang menjadi minat bersama; (3) menggunakan pedagogi kolaboratif dan kooperatif untuk membangun norma saling menolong dan membiarkan anak-anak mengalami cara kolaborasi yang 
bermanfaat bagi pembelajaran dan rasa saling memiliki; (4) menghindari kegiatan dan strategi kompetitif yang berupaya memotivasi anak-anak dengan membandingkan kinerjanya sehingga dapat memunculkan anggapan satu sama lain sebagai musuh; (5) memberikan kesempatan semua siswa dengan berbagai usia untuk saling mengenal dan membantu; (6) menggunakan pendekatan untuk mendisiplinkan yang menjaga hubungan peduli dengan dan di antara siswa; dan (7) menyampaikan kasih sayang dan kepedulian terhadap anak-anak yang secara konsisten berperilaku salah sehingga dapat menemukan cara untuk berperilaku lebih baik di masa depan.

\section{Mengajarkan Nilai-nilai Kemanusiaan}

Kegiatan dan pendekatan yang dilakukan dan dipilih guru bertujuan untuk membantu siswa memahami pentingnya nilai-nilai kemanusiaan, mengenali relevansinya dengan situasi sehari-hari, dan membangun keterampilan yang diperlukan untuk melaksanakan nilai-nilai tersebut. Pengajaran nilai-nilai manusiawi secara umum yang dilakukan guru, yaitu: (1) melibatkan anak-anak dalam memikirkan penataan kelas dan cara mewujudkan kelas seperti yang diinginkan. Cara semacam ini secara tidak langsung dapat menciptakan rasa kontrol siswa terhadap lingkungan, membantu siswa memahami nilai-nilai sesuai dengan aturan dan perilaku untuk dapat diterapkanan pada situasi lain; (2) menggunakan pendekatan disiplin yang membangun pemahaman dan keterampilan moral dan sosial siswa, membangun keterampilan empati sehingga dapat mencegah munculnya perilaku seperti itu di masa depan, dan memberikan kesempatan untuk menggunakan proses penyelesaian masalah sosial yang memperhitungkan kebutuhan semua pihak yang terlibat; (3) menggunakan pedagogi kolaboratif (pembelajaran kooperatif) yang sesuai sehingga membantu siswa mempelajari keterampilan dan sikap yang dibutuhkan untuk bekerja dengan orang lain secara adil, perhatian, bertanggung jawab, dan cara yang efektif; dan (4) menggunakan informasi yang disediakan dalam buku bacaan untuk membantu siswa melihat peran nilai-nilai kemanusiaan dalam kehidupan, membahas arti berbelas kasih, berprinsip, dan bertanggung jawab, dan memahami kehidupan dan keadaan orang lain yang beragam.

\section{Menghormati Motivasi Intrinsik}

Bertindak berdasarkan motivasi intrinsik untuk melakukan hal yang benar merupakan aspek utama dari karakter yang baik. Anak-anak secara alami akan menginternalisasi dan menerapkan nilai intrinsik tersebut ketika menjadi bagian dari komunitas peduli. Akan tetapi, upaya tersebut tidak akan berhasil jika guru menggunakan pendekatan motivasi ekstrinsik untuk melatih karakter siswa. Efek merusak dari teknik motivasi ekstrinsik pada motivasi intrinsik telah didokumentasikan oleh banyak psikolog dan pendidik (Deci \& Ryan, 1990; Kohn, 1991). Oleh karena itu, guru membantu siswa mengenali dan bertindak berdasarkan alasan intrinsik untuk berperilaku baik dengan beberapa cara berikut: (1) melibatkan anak-anak dalam berpikir tentang keinginannya terhadap situasi kelas dan cara mewujudkannya dan membangun motivasi intrinsik untuk hidup berdasarkan nilai-nilai tersebut; (2) secara teratur mengunakan pertemuan kelas untuk melibatkan siswa dalam pengambilan keputusan, memecahkan masalah, merefleksikan tujuan dan pencapaian mereka. Penyediaan forum yang aman untuk diskusi terbuka dapat menumbuhkan 
motivasi intrinsik untuk berkontribusi dan menjunjung tinggi keputusan bersama; (3) Dorong anak-anak untuk menetapkan tujuan pribadi untuk perbaikan dalam ranah intelektual dan sosial dan moral serta untuk merefleksikan kemajuan mereka; (4) mencari cara-cara bagi siswa untuk secara pribadi bertanggung jawab atas kontribusi pada kesejahteraan kelas, sekolah, komunitas, dan dunia yang lebih luas. Sebagai contoh, meminta siswa mengambil pekerjaan di kelas, melakukan pembersihan sekolah, menanam bunga di taman setempat, atau mengumpulkan dana untuk para korban bencana alam; dan (5) menggunakan pendekatan disiplin yang menekankan kolaborasi daripada paksaan, meminimalkan penggunaan pujian, penghargaan, dan hukuman, dan yang mengasumsikan siswa ingin hidup dengan norma dan nilai-nilai komunitas.

\section{Mengajarkan untuk Memahami}

Beberapa pendekatan dan kegiatan tambahan yang secara eksplisit berfokus pada pemahaman moral dalam jurnal yang dikaji dilakukan dengan cara: (1) memberikan berbagai peluang berbeda untuk menerapkan pengetahuan moral kepada anakanak; (2) melibatkan anak-anak dalam diskusi tentang masalah moral sehingga sekaligus belajar mendengar berbagai pendapat dari teman sekelas dan guru. Ide-ide berbeda semacam ini perlu digunakan untuk menantang siswa berpikir lebih kompleks; dan (3) menggunakan literatur sebagai konteks untuk diskusi moral. Siswa cenderung berpikir tingkat tinggi tentang situasi moral ketika tidak terlibat secara pribadi.

\section{Peran dan Tanggung Jawab Guru dalam Menciptakan Komunitas Peduli}

Anak-anak dididik agar memiliki karakter yang baik sehingga guru perlu mem- bangun keterampilan, kapasitas, dan pemahaman yang dibutuhkan untuk dapat bertindak sesuai prinsip dan nilai-nilai kemanusiaan sepanjang hidupnya. Guru yang ingin mengembangkan karakter siswa harus memiliki keterampilan moral, kepedulian, dan keterampilan sosial sehingga dapat menunjukkannya dalam kata dan tindakan. Guru harus memperhatikan kesejahteraan setiap siswa dan mampu menyeimbangkan kebutuhan siswa dengan kebutuhannya. Guru juga harus peka terhadap masalah moral yang tertanam dalam praktik pendidikan. Oleh karena itu, selain kualitas dan keprihatinan global seperti uraian di atas, guru perlu memiliki kemampuan berikut: (1) memahami perkembangan anak-anak dalam ranah sosial dan moral, serta peran sentral motivasi intrinsik dalam moralitas yang matang; (2) memahami peran otoritas orang dewasa di ruang kelas dan tanggung jawabnya dalam menjadikan ruang kelas tempat yang aman dan mendukung bagi semua siswa; (3) mengkomunikasikan dengan jelas kepada siswa harapan perilaku yang baik, perhatian, dan bertanggung jawab; (4) menyeimbangkan kebutuhan untuk menggunakan wewenang dengan kebutuhan untuk membentuk hubungan yang hangat dan mendukung aktivitas siswa, serta dengan kebutuhan otonomi siswa; (5) memahami anak-anak secara klasikal dan individual, menyadari kebutuhan dan harapan anakanak; (6) mewaspadai keterampilan sosial dan pengetahuan moral yang diperlukan untuk keberhasilan kinerja dalam situasi sekolah, sehingga dapat menjaga tantangan sosial dan moral dalam jangkauan siswa dan dapat memberikan dukungan sesuai kebutuhan; (7) menjadi pendengar yang baik; (8) mengantisipasi dan merencanakan situasi dengan hati-hati, tetapi juga cepat memahami dan merespons situasi tak 
terduga yang muncul di sekolah; (8) merasa nyaman mendiskusikan masalah etika yang sulit, seperti rasisme dan seksisme, dan dapat membantu siswa mengungkapkan pertanyaan dan memikirkan masalah tanpa takut dihina atau difitnah; dan (9) melibatkan dan mendukung siswa dalam menguasai kurikulum akademik yang relevan dan menantang.

Di bagian akhir dari tulisan ini perlu diberikan analisis singkat terhadap paparan hasil di atas. Masyarakat yang semakin beragam berdampak pada resiko polarisasi dan peningkatan konflik sosial. Komunitas yang saling menghargai dan mempromosikan pemahaman serta penghormatan terhadap orang lain, yang bersifat inklusif dan terbuka penting untuk dikembangkan. Dalam konteks ini, sekolah berperan sebagai institusi sosial yang menjangkau anggota dari beragam kelompok masyarakat. Pengajaran yang disengaja tentang karakter yang baik penting dalam masyarakat saat ini karena remaja menghadapi banyak peluang dan bahaya yang tidak diketahui oleh generasi sebelumnya. Para remaja harus mampu menghadapi lebih banyak pengaruh negatif yang dihadirkan media dan sumber eksternal lainnya. Selain itu, sekolah juga bertanggung jawab mengembangkan kemampuan dan kecenderungan yang diperlukan siswa untuk menjadi warga dalam demokrasi partisipatif. Akan tetapi, sekolah sering gagal membangun pemahaman asli siswa tentang teori dan konsep yang mendasari materi pelajaran karena hanya berfokus pada keterampilan, fakta, dan kapasitas siswa (Gardner \& BoixMansilla, 1994; Gardner, 1991; Goodlad, 1984). Hal tersebut disebabkan oleh kurangnya waktu luang yang diperlukan. Anakanak tidak hanya harus diberitahu cara bersikap, menghargai perilaku baik dan menghukum yang buruk, tetapi juga cara membangun pemahaman tentang konsep-konsep moral seperti keadilan dan tanggung jawab.

Fitur komunitas sekolah yang peduli bermanfaat bagi semua siswa, khususnya kelompok siswa yang memiliki kemungkinan paling kecil untuk berhasil di sekolah (Tharp, 1989). Cara sekolah peduli terhadap anak-anak tercermin dalam kepedulian terhadap keluarga mereka. Pendidik seharusnya memandang siswa sebagai anak-anak, dan bukan sebaliknya, sehingga keluarga dan masyarakat berperan sebagai mitra sekolah dalam pendidikan (Epstein, 2010). Kemitraan sekolah, keluarga, dan masyarakat dapat meningkatkan program dan iklim sekolah, menyediakan layanan dan dukungan keluarga, meningkatkan keterampilan dan kepemimpinan orang tua, dan yang terpenting adalah membantu semua anak muda berhasil di sekolah dan kehidupan selanjutnya. Keluarga dan sekolah secara tradisional dipandang sebagai agen sosialisasi yang penting nilai-nilai sosial remaja dan pandangannya tentang masyarakat (Zukin et al., 2006). Lingkungan sekolah yang positif berkontribusi pada pengembangan orientasi remaja yang bertanggung jawab secara sosial meskipun ada perubahan dalam masyarakat (Šerek, Macek, Ježek, \& Lacinová, 2014). Kepedulian juga harus diintegrasikan ke dalam semua program pengajaran sekolah. Teori kecerdasan ganda Gardner (1999) dapat menjadi salah satu cara untuk mengatur pengajaran karena berfokus pada pengembangan keterampilan interpersonal dan perilaku dibutuhkan siswa untuk menjadi orang dewasa yang berempati.

Pendidikan karakter menjadi gerakan nasional yang menciptakan sekolah dengan menumbuhkan generasi muda yang etis, bertanggung jawab, dan peduli dengan memberi contoh dan mengajar karakter yang baik melalui penekanan pada nilai-nilai universal. Pendidikan karakter merupakan upaya yang disengaja dan proaktif untuk menanamkan 
nilai-nilai etika inti yang penting kepada siswa, seperti kepedulian, kejujuran, keadilan, tanggung jawab, dan penghargaan terhadap diri sendiri dan orang lain (Pala, 2011). Karakter yang baik tidak terbentuk secara otomatis, tetapi dikembangkan dari waktu ke waktu melalui proses pengajaran, melalui pembelajaran dan praktik yang berkelanjutan. Anak-anak menghabiskan waktu sekitar 900 jam setahun di sekolah, sehingga penting agar sekolah melanjutkan peran proaktif dalam membantu keluarga dan masyarakat dengan mengembangkan lingkungan yang penuh perhatian dan saling menghormati di mana siswa belajar nilai-nilai inti dan etis. Ketika pendekatan komprehensif untuk pendidikan karakter digunakan, budaya moral positif dibuat di sekolah-lingkungan sekolah total yang mendukung nilai-nilai yang diajarkan di kelas (Rukiyati, 2013).

Pendidikan karakter telah dilakukan di sekolah dasar di Indonesia, baik negeri maupun swasta. Akan tetapi, manajemen pendidikan karakter di sekolah dasar belum efektif (Sasongko, 2018; Marzuki, Murdiono, \& Samsuri, 2011). Salah satu faktor yang berkontribusi terhadap ketidakefektifan tersebut adalah kurangnya dukungan orang tua dan masyarakat. Program pendidikan karakter yang efektif dan efisien harus mencakup strategi konteks khusus kurikulum yang sesuai dengan perkembangannya (Cicek, Ulker, \& Tarman, 2012). Strategi ini dirancang untuk mencapai pikiran sebagai domain kognitif, hati sebagai domain afektif dan kebiasaan sebagai domain perilaku (Lickona, 1985). Elemen-elemen pengembangan dan implementasi program pendidikan karakter secara komprehensif di sekolah dasar harus melibatkan administrator, guru, dan konselor dengan memberikan strategi, kegiatan, dan intervensi (Pearson \& Nicholson, 2000).

Salah satu strategi penciptaan komunitas peduli dalam artikel jurnal yang dianalisis dilakukan dengan menggunakan informasi yang disediakan dalam buku bacaan untuk membantu siswa melihat peran nilai-nilai kemanusiaan dalam kehidupan, membahas arti berbelas kasih, berprinsip, dan bertanggung jawab, dan memahami kehidupan dan keadaan orang lain yang beragam. Upaya semacam ini juga telah dilakukan di Indonesia dengan mengembangkan bahan ajar tematik integratif berbasis kearifan lokal (Lestaringsih \& Suardiman, 2017), berbasis scientific approach (Purnamasari \& Wangid, 2016) untuk meningkatkan karakter peduli dan tanggung jawab (Ariyani \& Wangid, 2016).

\section{SIMPULAN}

Kondisi masa kini yang sangat berbeda dengan masa lalu memerlukan pendekatan komprehensif dalam pelaksanaan pendidikan nilai dan moral. Implementasi pendekatan komprehensif, yang mencakupi isi, metode, proses di kelas, dan pelaksanaan pendidikan nilai atau pendidikan karakter di masyarakat seperti yang diuraikan dalam keempat artikel jurnal yang dikaji dalam tulisan ini, membekali siswa untuk mampu mengambil keputusan secara mandiri dalam memilih nilai-nilai yang saling bertentangan. Kepedulian yang ditandai dengan sikap baik dan penuh kasih sayang, menghargai orang lain, memaafkan orang lain, dan membantu orang lain penting untuk ditumbuhkembangkan di lingkungan keluarga, sekolah, dan masyarakat, terutama bagi anak-anak usia sekolah dasar (SD).

\section{UCAPAN TERIMA KASIH}

Terima kasih penulis ucapkan kepada Prof. Darmiyati Zuchdi, Ed.D., yang telah berkenan membimbing dan mereview tulisan ini. Ucapan terima kasih juga disampaikan kepada Ketua Dewan Redaksi Jurnal Pendidikan 
Karakter yang memproses artikel ini hingga layak publish pada edisi ini.

\section{DAFTAR PUSTAKA}

Arhar, J. M., \& Kromrey, J. D. (1993). Interdisciplinary teaming in the middle level school: Creating a sense of belonging for at-risk middle level students. Paper presented at the annual meeting of the American Educational Research Association, Atlanta, Georgia. 12-16 April 1993. Retrieved from https:/ / files.eric.ed.gov/fulltext/ED 364456.pdf.

Ariyani, D.Y., \& Wangid, M. N. (2016). Pengembangan bahan ajar tematik integratif berbasis nilai karakter peduli lingkungan dan tanggung jawab. Jurnal Pendidikan Karakter, 6(1), 116129. DOI: https://doi.org/10.21831/jpk.v0i1.10737.

Battistich, V.A. (2008). The child development project: Creating caring school communities. In Nucci, L.P., \& Narvaes, D. (Eds.), Handbook of moral and character education (p. 328-351). Routledge.

Battistich, V., Solomon, D., Watson, M., \& Schaps, E. (1994). Students and teachers in caring classroom and school communities. New Orleans: American Educational Research Association

Brandt, R. (1992). On building learning communities: A conversation with Hank Levin. Educational Leadership, 50, 19-23.

Brandt, R. (1989). On parents and schools: A conversation with Joyce Epstein." Educational Leadership, 24-27.
Bronfenbrenner, U. (1979). The ecology of human development: Experiment by nature and design. Cambridge: Harvard University Press.

Brophy, J. (1988). Teacher effects research and teacher quality. Journal of Classroom Interaction, 22(1), 14-23. Retrieved from https://www.jstor.org/stable/23869181.

Bryk, A.S., \& Driscoll, M.E. (1988). The school as community: Theoretical foundations, contextual influences, and consequences for students and teachers. Madison, WI: National Center on Effective Secondary Schools.

Cabello, B., \& Terrell, R. (1994). Making students feel like family: How teachers create warm and caring classroom climates. The Journal of Classroom Interaction, 29(1), 17-23. Retrieved from https://www.jstor.org/stable/23870 438.

Cicek, V., Ulker, R., Tarman, B. (2012). Comparison of character education in US and Turkish educational systems: Globalizing American education system. Energy Education Science and Technology Part B: Social and Educational Studies, 4(3), 1311-1322. Retrieved from https://www.academia.edu/19707400/Comparison_of_character_ education_in_US_and_Turkish_educ ational_systems_Globalizing_Americ an_education_system.

Connell \& Wellborn. (1990). What it takes to do well in school and whether I've got it: A process model of perceived control and children's engagement and achievement in school. Journal of 
Educational Psychology, 82(1), 22-32. DOI: $10.1037 / / 0022-0663.82 .1 .22$.

Connell, J.P. (1990). Context, selj and action: A motivational analysis of selfsystem processes across the life span. In D. Ciccheti \& Marjorie Beeghly (Eds.), The self in transition: Infancy to childhood. Chicago: University of Chicago Press.

Creemers, B.P.M. \& Tillema, H.H. (1988). The classroom as a social/emotional environment. Journal of Classroom Interaction, 23(2), 1-7.

Deci \& Ryan, 1990 Deci, E. L., \& Ryan, R. M. (1985). Intrinsic motivation and self-determination in human behavior. New York: Plenum.

Deci, E.L., \& Ryan, R.M. (1985). Intrinsic motivation and self-determination in human behavior. New York: Plenum.

Dewey, J. (1900). The school and society. Chicago: University of Chicago Press.

Dryfoos, J. (1994). Full-service schools. San Fransisco: Jossey-Bass.

Durkheim, E. (1961.). Moral education. New York: Free Press.

Eccles, J. S., \& Roeser, R. W. (2011). School and community influences on human development. In M.H. Bornstein \& M.E. Lamb (Eds.), Developmental science: An advanced textbook (p. 571643). Psychology Press.

Eccles, J.S., Midgley, C., Wigheld, A., Buchanan, C.M., Reuman, D., Flanagan, C., \& Mac Iver, D. (1993). Development during adolescence: The impact of stage-environment fit on young adolescents' experiences in schools and in families. American Psychologist, 48(2), 90-101. DOI: 10.1037/0003066X.48.2.90.

Epstein, J. L. (1987). Toward a theory of family-school connections: Teacher practices and parent involvement. In Hurrelmann, K.; Kaufmann, F.; and Losel, F. (eds.) Social Intervention: Potential and Constraints (121136). New York: DeGuyter.

Epstein, J.L. (2010). School/family/community partnerships: caring for the children we share. Phi Delta Kappan, 92(3), 81-96. DOI: 10.1177/003172171009200326.

Erikson, E. (1950). Childhood and society. New York: W.W. Norton.

Flores, B „ Cousin, P.T. \& Diaz, E. (1991). Transforming deficit myths about learning, language and culture. Language Arts, 68, 369-379. Retrieved from https://www.jstor.org/stable/41961877.

Gardner, H. (1991). The unschooled mind. New York: Basic Books

Gardner, H. (1999). The disciplined mind: What all students should understand. New York: Simon and Schuster.

Gardner, H., \& Boix-mansilla, V. ( 1994). Teaching and understanding within and across the disciplines. Educational Leadership, 51(5), 14-18. Retrieved from https://www.researchgate.net/publication/234725768_Teaching_fo r_Understanding_Within_and_Acros s_the_Disciplines. 
Glasser, W. (1969). Schools without failure. New York: Harper and Row.

Good, T. (1987). Two decades of research on teacher expectations: Findings and future directions. Journal of Teacher Education, 38(6), 9-15. DOI: https://doi.org/10.1177/002248718703800406

Goodenow, C. (1993). The psychological sense of school membership among adolescents: Scale development and educational correlates. Psychology in the Schools, 30(1), 79-90. DOI: https:/ / doi.org/10.1002/1520-6807(199301)30:1<79::AID-PITS2310300113>3.0.CO;2-X

Goodlad, J. (1984). A place called school: Prospects for the future. New York: McGraw-Hill

Hallinger, P., \& Murphy, J. F. (1986). The social context of effective schools. American Journal of Education, 94(3), 328-355. Retrieved from https://www.jstor.org/stable/1085156.

Hansen, D.A. (1989). Lesson evading and lesson dissembling: Ego strategies in the classroom. American Journal of Education, 97(2), 184-208. Retrieved from https://www.jstor.org/stable/1084910.

Haynes, N.M. (1996). Creating safe and caring school communities: Comer school development program schools. The Journal of Negro Education, 65(3), 308-314. Retrieved from https://www.jstor.org/stable/ 2967347.

Kohn, A. (1991). Caring kids: The role of the schools. Phi Delta Kappan, 72(7), 496-506. Retrieved from https:/ / eric.ed.gov/?id=EJ422809.
Lestaringsih, N., \& Suardiman, S. P. (2017). Pengembangan bahan ajar tematikintegratif berbasis kearifan lokal untuk meningkatkan karakter peduli dan tanggung jawab. Jurnal Pendidikan Karakter, 7(1), 86-99. DOI: https:/ /doi.org/10.21831/jpk.v7i1.1550.

Lewis, C.C., Schaps,E., \& Watson, M. (1995). Beyond the pendulum: Creating challenging and caring schools. Phi Delta Kappan, 76(7), 547-554. Retrieved from https://www.proquest.com/openview/987e09499d971 8314e2cea787bbbbc92/1?pq-origsite$=$ gscholar\&cbl=41842.

Li, A.K.F. (1992). Peer relations and social skills training: Implications for the multicultural classroom. Journal of Educational Issues of Language Minority Students, 10, 67-7.

Lickona T. (1985). Raising good children from birth through the teenage years. Toronto: Bantam.

Marzuki, Murdiono, M., \& Samsuri,. (2011). Pembinaan karakter siswa berbasis pendidikan agama. Jurnal Kependidikan, 41(1), 45-53. DOI: https://doi.org/10.21831/jk.v41i1.1919.

McMillan, D.W., \& Chavis, D.M. (1986). Sense of community: A definition and theory. Journal of Community Psychology, 14(1), 6-23. DOI: 10.1002/1520-6629(198601)14:13.0.CO;2-I

Noddings, N. (1994). Conversation as moral education. Journal of Moral Education, 23(2), 107-118. DOI: https://doi.org/10.1080/0305724940230201.

Noddings, N. (2002). Educating moral people. New York: Teachers College Press. 
Noddings, N. (2005). The challenge to care in schools, 2nd ed. New York: Teachers College Press.

Pala, A. (2011). The need for character education. International Journal of Social Sciences and Humanity Studies, 3(2), 23-32. Retrieved from https://www.sobiad.org/eJOURNALS/jour nal_IJSS/arhieves/2011_2/aynur_pal a.pdf.

Pearson, Q.M., \& Nicholson, J.I. (2000). Comprehensive character education in the elementary school: strategies for administrators, teachers, and counselors. The Journal of Humanistic Counseling, Education and Development, 38(4), 243-251. DOI: 10.1002/j.2164-490x.2000.tb00085.x

Perry, Kelder, \& Komro, 1993 (Perry, T. (1993). Toward a theory of African American school achievement. Report 16 Baltimore: Center on Families, Communities, Schools and Children's Learning. John Hopkins University.

Purnamasari, V., \& Wangid, M. N. (2016). Pengembangan perangkat pembelajaran berbasis scientific approach untuk membangun karakter kepedulian dan kedisiplinan. Jurnal Pendidikan Karakter, 6(2), 167-180. DOI: https://doi.org/10.21831/jpk.v6i2.12047.

Rosenholtz, S. (1989). Teachers'workplace: The social organization of schools. New York: Longman

Rukiyati. (2013. Urgensi pendidikan karakter holistik komprehensif di Indonesia. Jurnal Pendidikan Karakter, 3(2), 196-203. DOI: https://doi.org/10.21831/jpk.v2i2.1440.
Sasongko, R.,N. (2018). Determining factors of success of character education management and its implementation facing of the era of industrial revolution 4.0: An analysis at elementary school, Province of Bengkulu. Advances in Social Science, Education and Humanities Research, 295, 74-79. DOI: https://doi.org/10.2991/icetep-18.2019.18.

Schaps, E., \& Solomon, D. (1990). Schools and classrooms as caring communities. Educational Leadership, 48, 38-42.

Šerek, J., Macek, P., Ježek, S., \& Lacinová, L. (2014). Twenty years after the Velvet Revolution: Shifts in Czech adolescents' perceptions of family, school and society. Journal of Adolescent Research, 29(6), 738-764. DOI: http://dx.doi.org/10.1177/0743558414538315.

Sizer, T. (1984). Horace's compromise: The dilemma of the American high school. Boston: Houghton Mifflin.

Tharp, R. G. (1989). Psychocultural variables and constants: Effects on teaching and learning in schools. American Psychologist, 44(2), 349-359. DOI: https://doi.org/10.1037/0003066X.44.2.349

Watson, M. (1999). The child development project: building character by building community. Action in Teacher Education, 20(4), 59-69, DOI: 10.1080/01626620.1999 .10462935

Zukin, C., Keeter, S., Andolina, M., Jenkins, K., \& Delli Carpini, M. X. (2006). A new engagement? Political participation, civic life, and the changing American citizen. Oxford, New York: Oxford University Press. 